\title{
ESTIMATES OF GENETIC DIVERGENCE IN COWPEA BY MULTIVARIATE ANALYSIS IN DIFFERENT ENVIRONMENTS
}

\author{
ESTIMATIVA DE DIVERGÊNCIA GENÉTICA EM FEIJÃO-CAUPI POR MEIO DE \\ ANÁLISE MULTIVARIADA EM DIFERENTES AMBIENTES
}

\author{
Larissa Pereira Ribeiro TEODORO ${ }^{1}$; Jeniffer Santana Pinto Coelho EVANGELISTA ${ }^{2}$; \\ Michelle Brandão DAMACENA ${ }^{2}$; Arthur Mayrink ELIZEU ${ }^{2}$; Igor Ferreira COELHO ${ }^{2}$; \\ Erina Vitório RODRIGUES ${ }^{3}$; Paulo Eduardo TEODORO ${ }^{1^{*}}$; Leonardo Lopes BHERING ${ }^{2}$ \\ 1. Universidade Federal de Mato Grosso do Sul, Campus de Chapadão do Sul, Chapadão do Sul, MS, Brasil 2. Departamento de \\ Biologia Geral, Universidade Federal de Viçosa, Viçosa, MG, Brasil; 3. Universidade Federal de Brasília, Planaltina, DF, \\ Brasil.*:eduteodoro@hotmail.com
}

\begin{abstract}
Cowpea is a legume of great importance in the Brazilian nutrition, mainly in the Northeast region. Despite the low yield of Brazilian cowpea, the species presents a genetic potential to be explored. Thus, this work aimed to characterize the genetic diversity of cowpea genotypes by agronomic traits and select genotypes for possible crosses by multivariate analysis. Four value for cultivation and use tests were carried out with cowpea genotypes in 2005 and 2006, in the municipalities of Aquidauana, Chapadão do Sul, and Dourados, in the state of Mato Grosso do Sul. The experimental design was a complete randomized block with 20 genotypes and four replications. The evaluated traits were value for cultivation, plant lodging, pod length, grain weight of five pods, number of grains per pod, pod weight, severity of powdery mildew, and grain yield. To estimate the genetic diversity among the genotypes, the optimization methods of Tocher and UPGMA were used. The generalized distance of Mahalanobis was used as a dissimilarity measure. The clustering methods revealed genetic variability among the cowpea genotypes evaluated. The methods used formed a different number of groups for each environment. Genotypes TE97-309G-24, MNC99-542F-5, BRS Paraguaçu, BRS Paraguaçu, BR 17-Gurguéia, and CNC x 409-11F-P2 can be used to obtain promising combinations and high genetic variability.
\end{abstract}

KEYWORDS: Vigna unguiculata L.. Dissimilarity. UPGMA. Tocher.

\section{INTRODUCTION}

Cowpea (Vigna unguiculata (L.) Walp.) is a legume of high relevance in the Brazilian nutrition, mainly in the Northeast region. The species is an important source of proteins, carbohydrates, vitamins, minerals, and plant dietary fibers (FREIRE FILHO et al., 2011). Originally from Africa, cowpea was introduced in Brazil in the state of Bahia by the Portuguese settlers in the second half of the 16th century (FREIRE FILHO, 2011). Since its introduction, it has spread all over the country.

The Brazilian production in the 2015/2016 crop season was of $649,000 \mathrm{Mg}$, most in the Northeast region $(376,700 \mathrm{Mg})$. However, the mean cowpea yield in Brazil is still low (338 $\mathrm{kg} \mathrm{ha}^{-1}$ ) (CONAB, 2017), which shows the need for investments in technology. In the Brazilian Midwest, yield reaches $1,285 \mathrm{~kg} \mathrm{ha}^{-1}$, which is higher than the national mean, especially due to the high technological management applied to the crops in this region. However, the species presents genetic potential to exceed $6,000 \mathrm{~kg} \mathrm{ha}^{-1}$, demonstrating that its yield potential has been little explored (PASSOS et al., 2007).

The breeding of self-pollinated species, such as cowpea, is mainly based on the selection of parents, followed by hybridization to obtain the base population and advance the generations. In this context, studies on the genetic diversity are fundamental since they provide estimates for the identification of parents which, when crossed, increase the chances of selecting superior genotypes in segregating generations (CRUZ et al., 2012).

Thus, studies on the genetic diversity are necessary to select divergent genotypes and predict the specific combining ability and the heterosis of the parents with the highest potential for the desired agronomic traits. Such studies help to improve the identification of contrasting parents, which consequently highlights the most promising combinations, allowing the recovery of advanced superior lines (FALCONER et al., 1987). Even the breeder concentrates his efforts only on the most promising crosses.

One way to evaluate the genetic divergence is by using multivariate techniques, which are 
carried out by the simultaneous evaluation of several traits that allow numerous inferences. Hierarchical methods and optimization methods are examples of multivariate techniques by clustering methods. In the first case, genotypes are clustered in a process that repeats at several levels until the dendrogram is established, without the concern for the optimal number of groups, such as the UPGMA (Unweighted Pair Group Mean Average) method. In optimization methods, parents are divided into subgroups by a pre-established criterion. One of the most used optimization methods is the Tocher's clustering (RAO et al., 1981), in which the mean of intra-group dissimilarity measures should be lower than the mean of the inter-group distances (CRUZ et al., 2012).

These clustering methods have been used in cowpea (OLIVEIRA et al., 2003; PASSOS et al., 2007, BERTINI et al., 2009, ALMEIDA et al., 2011, SANTOS et al., 2014) and they are intended to reduce the number of traits and consequently simplify the obtainment of genetic distances (CORREA; GONÇALVES, 2012). Given the above, this study aimed to characterize the genetic variability of agronomic traits and estimate the genetic divergence among cowpea genotypes by multivariate analysis.

\section{MATERIAL AND METHODS}

Four value for cultivation and use testing were carried with cowpea genotypes out in 2005 and 2006, in the municipalities of Aquidauana, Chapadão do Sul, and Dourados, in the state of Mato Grosso do Sul. The experimental design was a randomized complete block with 20 treatments and four replications. The experimental unit consisted of four 5.0-m rows, spaced at $0.5 \mathrm{~m}$ between rows, and $0.25 \mathrm{~m}$ between plants, considering the two central rows as the useful area.

Treatments consisted of 20 cowpea genotypes (1- MNC99-505G-11, 2- MNC99-507G-4, 3- MNC99507G-8, 4- MNC99-510G-8, 5- TE96-290-12G, 6MNC99-510F-16, 7- TE97-309G-18, 8- TE97-304G4, 9- TE97-304G-12, 10- TE97-309G-24, 11MNC99-508G-1, 12- MNC99-541F-15, 13- MNC99541F-18, 14- MNC99-541F-21, 15- MNC99-542F-5, 16- MNC99-542F-7, 17- MNC99-547F-2, 18- BRS Paraguaçu, 19- BR 17-Gurguéia, and 20- CNC x 409-11F-P2) from the cowpea breeding program of Embrapa Meio-Norte.

The following traits were evaluated: value for cultivation (VC), obtained according to the general appearance of the plant in the plot using a score scale (from 1 to 5) pre-established for the crop; plant lodging (LOD), obtained by using a score scale (from 1 to 5) pre-established for the crop; pod length (PL), expressed in centimeters $(\mathrm{cm})$, obtained by the mean of five pods randomly taken from the plot area; grain weight of five pods (GWP), expressed in grams (g), evaluated in pods randomly taken from the plot area; number of grains per pod (NGP), evaluated in the grains of five pods taken from each plot area; pod weight (PW), expressed in grams $(\mathrm{g})$, obtained from a sample of five pods randomly taken from the plot area; severity of powdery mildew (SPM), assessed by using a score scale (from 1 to 5); and grain yield (GY), obtained by the relation between the plot grain production and its respective area extrapolated to $\mathrm{kg} \mathrm{ha}^{-1}$.

Data were subject to individual analysis of variance for each environment (Chapadão do Sul 2005, Aquidauana -2005, Dourados-2006, and Aquidauana-2006). The homogeneity of residual variances was tested by the ratio between the largest and the smallest mean squared error (MSE), considering seven as the limit value to meet this assumption, as described by Pimentel-Gomes \& Garcia (2002). Homogeneity of variances was detected, which made possible the joint analysis, considering the following model: $\mathrm{Y}_{\mathrm{ijk}}=\mathrm{m}+\mathrm{Gi}+$ $\mathrm{B} / \mathrm{E}_{\mathrm{jk}}+\mathrm{E}_{\mathrm{j}}+\mathrm{GE}_{\mathrm{ij}}+e_{\mathrm{ijk}}$, wherein, $\mathrm{Y}_{\mathrm{ijk}}=$ effect of the $\mathrm{i}$-th genotype in the $\mathrm{j}$-th environment and $\mathrm{k}$-th block; $\mathrm{m}=$ constant and overall; $\mathrm{G}_{\mathrm{i}}=$ fixed effect of the ith genotype $(i=1,2, \ldots, 20) ; \mathrm{B} / \mathrm{E}_{\mathrm{jk}}=$ effect of the block within the environment; $E_{j}=$ random effect of the $j$-th environment $(j=1,2,3,4) ; E_{j} \sim \operatorname{NID}\left(0, \sigma^{2}\right)$; $\mathrm{GE}_{\mathrm{ij}}=$ effect of the interaction of the $\mathrm{i}$-th genotype with the $\mathrm{j}$-th environment; and $e_{\mathrm{ijk}}=$ error associated with the observation $Y_{\mathrm{ijk}}, e_{\mathrm{ijk}} \sim \mathrm{NID}\left(0, \sigma^{2}\right)$.

To estimate the matrix of genetic diversity among cowpea genotypes, the Mahalanobis method was used, which is indicated for experiments with experimental design. The Tocher's optimization method (RAO, 1981) was applied by using the Genes software (CRUZ, 2013). The Tocher's optimization method is based on the dissimilarity matrix expressed by $\mathrm{D}^{2}$, on which the most similar pairs of genotypes are identified, aiming at forming the initial group. As a criterion for the inclusion of new genotypes in the group, the mean intra-group distance should be smaller than the mean intergroup distance. Based on the distance matrix (CRUZ et al., 2012), the UPGMA method was applied using the R software (R Development Core Team, 2015). 


\section{RESULTS AND DISCUSSION}

Genotypes presented significant differences $(p<0.01)$ for all traits evaluated, evidencing the existence of genetic variability, except for plant lodging (LOD) (Table 1). This circumstance allows the separation into contrasting groups, which will form future crosses in a breeding program (CARVALHO et al., 2017). The effects of genotypes $\mathrm{x}$ environments interaction were significant $(p<0.01)$ for the traits value for cultivation, plant lodging, severity of powdery mildew, and grain yield, indicating that, for these traits, genotypes presented a differentiated performance in the different environments. These results justify the use of VCUs for a suitable cultivars recommendation.

Table 1. Summary of joint analysis of variance for the traits value for cultivation (VC), plant lodging (LOD), severity of powdery mildew (SPM), pod length (PL), grain weight of five pods (GWP), number of grains per pod (NGP), pod weight (PW), and grain yield (GY) evaluated in 20 cowpea genotypes.

\begin{tabular}{|c|c|c|c|c|c|c|c|c|c|}
\hline \multirow{2}{*}{ FV } & \multirow{2}{*}{$\mathrm{DF}$} & \multicolumn{8}{|c|}{ Mean Squares } \\
\hline & & $\mathrm{VC}$ & LOD & SPM & PL & GWP & NGP & PW & GY \\
\hline Block & 3 & 0.72 & 0.22 & 2.94 & 10.33 & 51.96 & 199.81 & 70.57 & 375144.67 \\
\hline Genotypes (G) & 19 & $2.74^{* *}$ & $1.38^{\mathrm{ns}}$ & $5.38^{* *}$ & $21.84^{* *}$ & $19.66^{* *}$ & $496.79^{* *}$ & $38.22^{* *}$ & $217993.74^{* *}$ \\
\hline Environments (E) & 3 & $64.38^{* *}$ & $37.54^{* *}$ & $113.10^{* *}$ & $20.14^{*}$ & $474.41^{* *}$ & $1112.12^{* *}$ & $544.22^{* *}$ & $11119248.89^{* *}$ \\
\hline Gx E & 57 & $0.86^{* *}$ & $0.94^{* *}$ & $2.28^{* *}$ & $1.64^{\mathrm{ns}}$ & $4.79^{\mathrm{ns}}$ & $66.20^{\mathrm{ns}}$ & $5.61^{\mathrm{ns}}$ & $70428.63^{* *}$ \\
\hline Error & 228 & 0.40 & 0.37 & 0.79 & 1.54 & 3.55 & 67.15 & 4.77 & 30601.82 \\
\hline Mean & - & 3.90 & 1.79 & 3.92 & 18.63 & 10.46 & 60.25 & 14.64 & 587.14 \\
\hline $\mathrm{CV}$ & - & 16.25 & 33.84 & 22.75 & 6.66 & 18.02 & 13.60 & 14.92 & 29.79 \\
\hline
\end{tabular}

The mean yield of the environments was considered as low. The significant genotypes $\mathrm{x}$ environments interaction suggest the existence of superior means, which allows performing selection by the environment. Corroborating this information, Correa \& Gonçalves (2012) evaluated the potential for genetic breeding of a cowpea population in the municipality of Aquidauana and found yield values higher than those of this study. The coefficient of variation $(\mathrm{CV})$ expressed the experimental accuracy. Values ranged from $6.66 \%$, for the trait pod length (PL), to $33.84 \%$, for lodging (LOD). Other studies have reported CVs at this magnitude (SANTOS et al.,2014; TORRES et al. 2015, 2016, and BARROSO et al., 2016).

The dissimilarity of genotypes in the studied environments, expressed by the Mahalanobis distances $\left(D^{2}\right)$, showed larger amplitudes in the municipalities of Chapadão do Sul and Aquidauana in 2005, whereas in the other environments, the values were more similar. According to Falconer (1987), the genetic variability of a segregating population depends on the genetic divergence and parents involved in the cross. Most of the time, the primary objective of a breeding program at the initial phase is to increase the grain yield; therefore, converging crosses are also essential to achieve this goal more quickly.
Singh et al. (2018) carried out studies on genetic divergence in 38 cowpea genotypes evaluated in two environments, based on the $\mathrm{D}^{2}$ matrix. Based on the genetic divergence, the genotypes were clustered in ten and five groups in environments 1 and 2, respectively. These authors concluded that these groups and their genotypes could be inter-crossed to achieve higher genetic variability for the breeding program.

In this way, eight, six, six, and seven groups were obtained for the environments of Chapadão do Sul - 2005, Aquidauana - 2005, Dourados - 2006, and Aquidauana - 2006, respectively (Table 2). Six groups were formed by the Tocher's optimization method for environments Aquidauana - 2005 and Dourados - 2006. The pairs of more similar groups were I and II, for the first environment, with a mean distance of 12,487 ; and I and IV, for the second environment, with a mean distance of 1.071 .

The groups of genotypes with the highest dissimilarity were III (TE97-309G-24 and BR 17Gurguéia) and IV (MNC99-541F-21 and MNC99542F-5); and II (MNC99-541F-21, MNC99-547F-2, and CNC x 409-11F-P2) and VI (BRS Paraguaçu), with mean distances of 40.035 and 2.71, respectively. In the environment Chapadão do Sul, genotypes of groups III (MNC99-508G-1 and BRS Paraguaçu) and VIII (CNC x 409-11F-P2) had higher mean dissimilarity (63.815). Conversely, 
genotypes of groups I (lines MNC99-505G-11, MNC99-507G-8, MNC99-510F-16, TE97-304G-4, TE96-290-12G, MNC99-510G-8, TE97-304G-12, and MNC99-541F-18) and VII (TE97-309G-18) obtained the lowest mean dissimilarity (13.269).

Table 2. Cluster analysis of 20 cowpea genotypes by the Tocher's optimization method, evaluated in four sites.

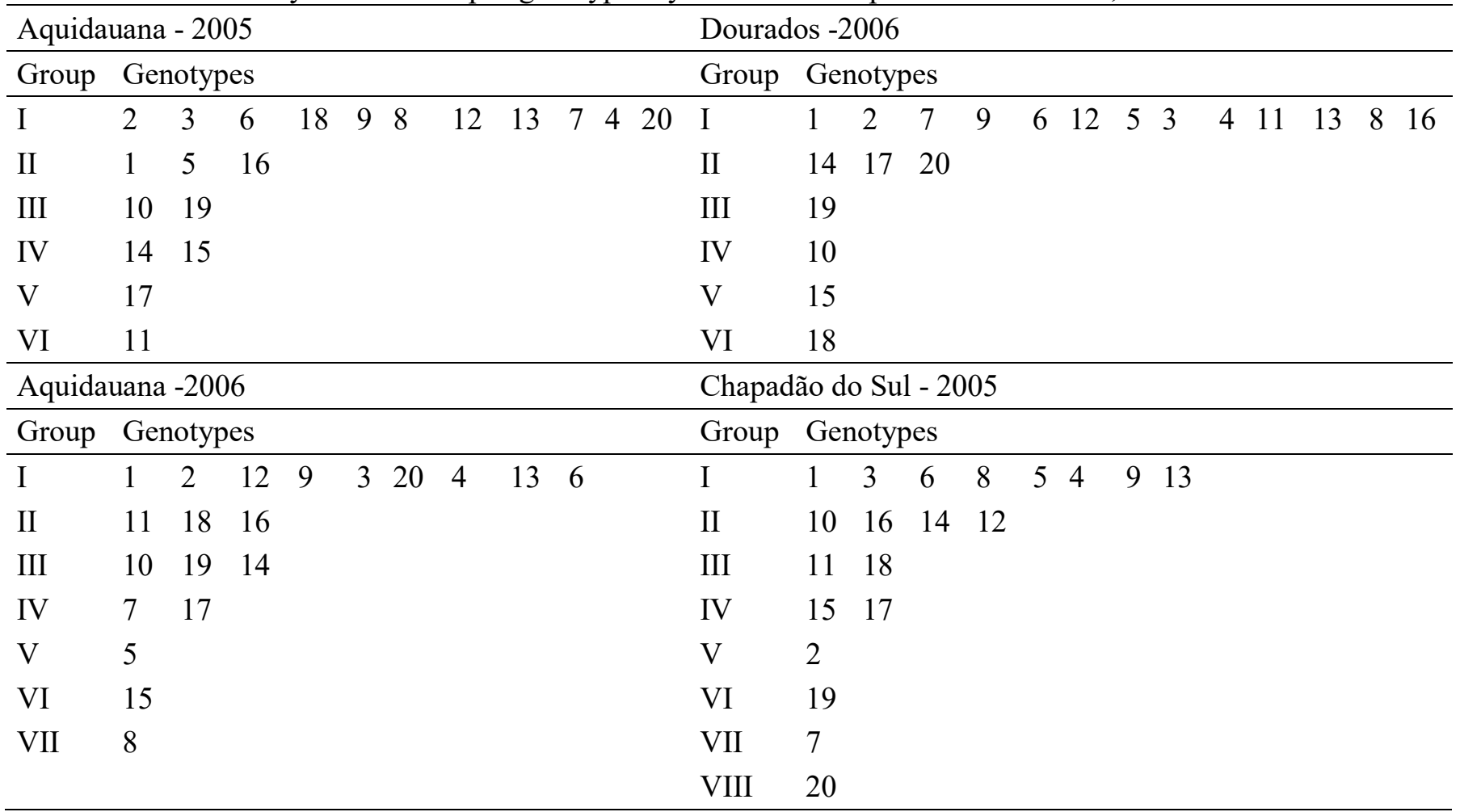

Souza et al. (2017), by studying the genetic diversity of cowpea genotypes in the southern Tocantins, also found the formation of different clusters using the Tocher's and UPGMA clustering methods. According to their results, when using the Tocher's method, genotypes were separated into nine groups, while in the dendrogram obtained by the UPGMA method, genotypes were organized into five groups. Therefore, combinations of genotypes from different groups can generate promising populations. To identify superior combinations, aiming at the genetic crosses to obtain superior cultivars, the distinct groups formed can be analyzed with their respective distances.

Patel et al. (2017) evaluated the genetic divergence in 32 cowpea genotypes for grain yield and reported the formation of eight groups. The authors stated that group eight was the most divergent, in addition to being composed of genotypes with higher means for yield components. Therefore, they concluded that genotypes belonging to this group should be crossed to generate more variability.

The genetic diversity expressed by genotypes that are components of the pairs of groups evidences their potential as parents for hybrid combinations. This fact would result in progenies with a broad genetic base and a higher probability of obtaining new genetic combinations with characteristics for high yield potential in segregating generations (OLIVEIRA et al., 2003).

Thus, genotypes belonging to pairs of groups of higher divergence are the most suggested for the hybrid combination in future breeding programs developed for the environments used in the present study. This fact generates the expectation of obtaining hybrids of greater heterotrophic effect due to the genetic divergence between the recombined lines. Thus, the genetic segregation allows a genetic variability in the selection of agronomically superior/promising genotypes.

In genetic diversity studies, applying more than one clustering method is usual since each one has its own particularity. Moreover, results should be presented based on the criteria of each method. From the genetic dissimilarity of the genotypes, the dendrograms formed by the UPGMA method were presented in each distinct environment. In the municipalities of Chapadão do Sul and Aquidauana, 2006, two large groups were obtained, while in Aquidauana 2005 and Dourados 2006, the 
genotypes were separated into two groups (Figure $1)$.

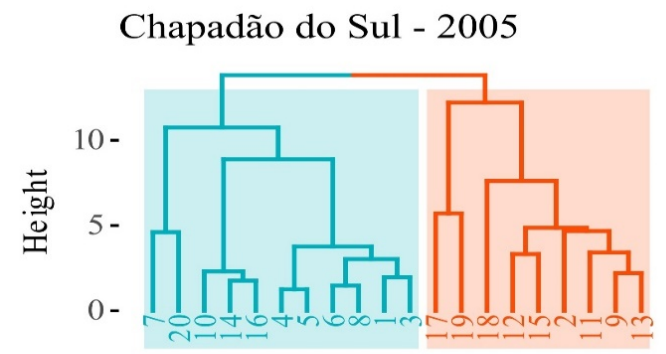

Dourados - 2006

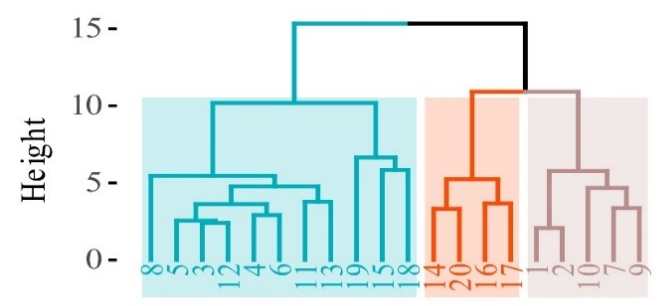

Aquidauana - 2005

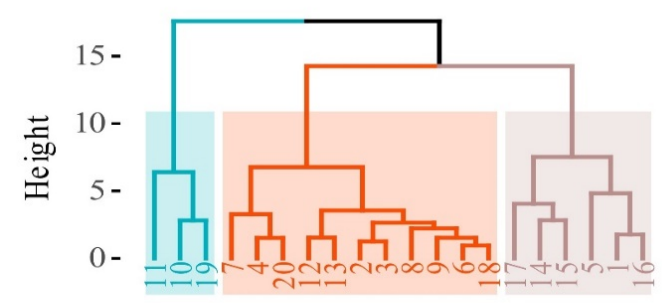

Aquidauana - 2006

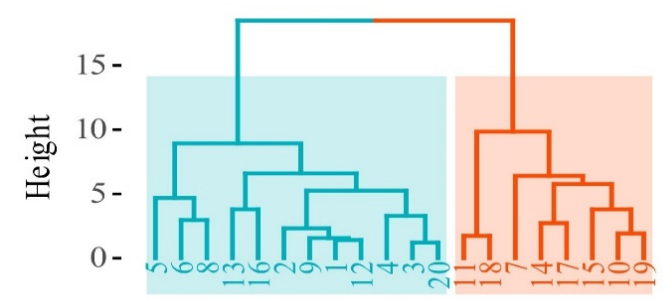

Figure 1. Cluster analysis of 20 cowpea genotypes by the UPGMA method (Unweighted Pair-Group Method Arithmetic Average) at $75 \%$ of the last level of fusion.

In the municipality of Chapadão do Sul (Figure 1), the highest estimates of genetic dissimilarity were detected between the pairs of genotypes BRS Paraguaçu and CNC x 409-11F-P2 $\left(\mathrm{D}^{2}=73.92\right)$; BR 17-Gurguéia and CNC x 409-11F$\mathrm{P} 2\left(\mathrm{D}^{2}=57.09\right)$; MNC99-508G-1 and CNC x 40911F-P2 $\left(\mathrm{D}^{2}=53.71\right)$; and TE97-309G-18 and BR 17-Gurguéia. This is an interesting result since the CNC x 409-11F-P2 participated in most of the most dissimilar pairs. This result can be justified by the fact that the genotype is of North American origin, i.e., its gene pool contributed to greater genetic divergence. Thus, this genotype can be inserted in cross blocks in future cowpea breeding programs.

The municipality of Aquidauana (Figure 1) presented distinct clustering according to the crop year. This is the result of the genotypes $\mathrm{x}$ environments interaction. In 2005, the pairs of genotypes TE97-309G-24 and BR 17-Gurguéia composed the same group, regardless of the crop year, showing that these genotypes have a high genetic similarity; therefore, crosses between them are not recommended. However, the cross between genotypes TE97-309G-24 and MNC99-510G-8 has higher chances of obtaining segregating populations since the genotypes make up different groups and have a high genetic dissimilarity value $\left(D^{2}=41.82\right)$ when compared with the others.

Although different groups were formed in the municipalities of Aquidauana (Figure 1), the genotypes contained in each group remained constant, i.e., the $\mathrm{G} \times \mathrm{E}$ interaction influenced the number of groups but did not influence the genotype ranking within each group. However, the evaluation in environments sets becomes essential to better evaluate the $\mathrm{G} \times \mathrm{E}$ interaction and obtain a reliable cluster. Since the evaluations are performed on the phenotypes, which may change depending on the environment, erroneous interpretations may occur when the researcher does not use groups of environments to assess genetic divergence by multivariate analysis.

By assessing the genetic divergence and stability in cowpea, Prasad (2016) also observed that the environment was a dominant source of variation for almost all traits. For the development of stable and yielding genotypes, the parents must have high yield potential and less interaction with the test environments.

\section{CONCLUSION}

The clustering methods used in this study revealed the genetic variability among the cowpea genotypes evaluated. The methods formed different numbers of groups for each environment. Genotypes TE97-309G-24, MNC99-542F-5, BRS Paraguaçu, BRS Paraguaçu, BR 17-Gurguéia, and CNC x 409$11 \mathrm{~F}-\mathrm{P} 2$ can be used to obtain promising combinations and high genetic variability. 
RESUMO: O feijão-caupi é de grande importância na nutrição brasileira, principalmente na região Nordeste. Apesar do baixo rendimento do feijão-caupi no Brasil, esta leguminosa apresenta potencial genético a ser explorado. Dessa forma, o objetivo do trabalho foi caracterizar a variabilidade genética de caracteres agronômicos e estimar a divergência genética entre genótipos de feijão-caupi por meio de análise multivariada. Quatro ensaios de valor de cultivo e uso com genótipos de feijão-caupi foram conduzidos nos anos de 2005 e 2006, nos municípios de Aquidauana, Chapadão do Sul e Dourados. Os experimentos foram conduzidos em delineamento blocos casualizados, com 20 genótipos e quatro repetições. Os caracteres avaliados foram acamamento de plantas, comprimento de vagem, peso de grãos de cinco vagens, número de grãos por vagem, peso de vagem e produtividade de grãos. Realizou-se análise de variância individual e conjunta. Para estimar a diversidade genética entre os genótipos, foram utilizados o métodos de otimização de Tocher e UPGMA. A distância generalizada de Mahalanobis foi utilizada como medida de dissimilaridade. Foi possível detectar variabilidade genética entre os genótipos de feijão-caupi avaliados por meio dos métodos de agrupamento utilizados. Os métodos utilizados formaram números de grupos distintos para cada ambiente. Os genótipos TE97-309G-24, MNC99-542F-5, BRS Paraguaçu, BRS Paraguaçu, BR 17-Gurguéia e CNC x 409-11F-P2 podem ser usados para obter combinações promissoras e elevada variabilidade genética.

PALAVRAS-CHAVE: Vigna unguiculata L. Dissimilaridade. UPGMA. Tocher.

\section{REFERENCES}

ALMEIDA W. S.; BELEM, F. R. F.; BERTINI C. H. C. M.; PINHEIRO M. S.; TEOFILO E. M. Identificação de genótipos de feijão caupi tolerantes a salinidade avaliado por meio de método multivariado. Ciencia Rural. v. 41, n. 11, p. 1884-1889, 2011. https://doi.org/10.1590/S0103-84782011001100006

BARROSO, L. M. A.; TEODORO, P. E.; NASCIMENTO, M.; TORRES, F.E. ; dos SANTOS, A.; CORREAA, A. M.; SAGRILO, E.; CORRÊA, C. C. G.; SILVA, F.A.; CECCON, G. Bayesian approach increases accuracy when selecting cowpea genotypes with high adaptability and phenotypic stability. Genet. Mol. Res, v. 16, n. 1, 2016. https://doi.org/10.4238/gmr.15017625

CARVALHO, A. F.; SILVA, G. O. Divergência genética entre genótipos de cenoura através de caracteres agronômicos. Revista Agro@mbiente On-line, v. 11, n. 2, p. 137-144, 2017. https://doi.org/10.18227/19828470ragro.v11i2.3642

COMPANHIA NACIONAL DE ABASTECIMENTO - CONAB. Sexto levantamento de safras brasileiras de grãos, março 2017. <Disponível em: http:// www.conab.gov.br/OlalaCMS/uploads/ arquivos/17_03_14_15_28_33_boletim_graos_marc o_2017bx.pdf $>$. Acesso em: 29 mar. 2017.

CORREA, A. M.; GONÇALVES, M. C. Divergência genética em genótipos de feijão comum cultivados em Mato Grosso do Sul. Ceres, v. 59, n. 2, 2012. https://doi.org/10.1590/S0034-737X2012000200009

CRUZ, C. D.; REGAZZI, A. J.; CARNEIRO, P. C. S. (2012). Modelos biométricos aplicados ao melhoramento genético. Viçosa: UFV, v. 4, p. 514, 2012.

CRUZ, C. D. GENES - a software package for analysis in experimental statistics and quantitative genetics. Acta Scientiarum Agronomy, Maringá, v. 35, n. 3, p. 271-276, 2013. Disponível em: https://dx.doi.org/10.4025/actasciagron.v35i3.21251.

FALCONER, D. S. Introdução à genética quantitativa. Viçosa: UFV, p. 279, 1987.

FREIRE FILHO, F. R.; RIBEIRO, V. Q.; ROCHA, M. de M.; DAMASCENO-SILVA, K. J.; NOGUEIRA, M. do S. da R.; RODRIGUES, E. V. Feijão-caupi: produção, melhoramento genético, avanços e desafios. Brasília, DF: Embrapa Informação Tecnológica. 81 p. 2011. 
OLIVEIRA, F. J.; FILHO, C. J. A.; BASTOS, G.Q.; REIS, O. V. Divergência genética entre cultivares de caupi. Pesquisa Agropecuária Brasileira. V. 38, n. 5, p. 605-611, 2003.

PASSOS, A. R.; SILVA, A. S.; CRUZ, P. J.; ROCHA, M. M.; CRUZ, E. M. O.; ROCHA, M. A. C.; BAHIA, H. F.; SALDANHA R. B. Divergência genética em feijão-caupi. Bragantia, v.66, n. 4, p. 579-586, 2007. https://doi.org/10.1590/S0006-87052007000400007

PATEL, U. V.; PARMAR, V. K.; TANDEL, Y. N.; PATEL, H. R. Genetic divergence in cowpea [Vigna unguiculata (L.) Walp.] for yield components parameters. Electronic Journal of Plant Breeding, v. 8, n. 1, p. 331-335, 2017. https://doi.org/10.5958/0975-928X.2017.00049.7

PRASAD, S. Seed heteromorphism, seed quality assessment, genetic divergence and stability analysis in cowpea [Vigna unguiculata (L.) Walp]. Tese de Doutorado. GB Pant University of Agriculture and Technology, Pantnagar (Uttarakhand). 2016.

RAO, A. V.; PRASAD A. S. R.; SAI KRISHNA T.; SECHU D. V.; SRINIVASAN T. E. Genetic divergence among some brown planthopper resistant rice varieties. The Indian Journal of Genetic Plant Breending, $v$. 41, n. 2, p. 179-185, 1981.

SANTOS, J. A. da S.; SOARES, C. M. G.; CORRÊA, A. M.; TEODORO, P. E.; RIBEIRO, L. P.; ABREU, H. K. A. de. Agronomic performance and genetic dissimilarity among cowpea (Vigna unguiculata (L.) Walp.) genotypes. Global Advanced Research Journal of Agricultural Science, v. 3, p. 271-277, 2014.

SINGH, O. V.; SHEKHAWAT, N.; SINGH, K.; GOWTHAMI, R. Genetic Divergence Studies in Cowpea [Vigna unguiculata (L.) Walp.] Germplasm using Mahalanobis $D^{2}$ Analysis. Int. J. Curr. Microbiol. App. Sci, v. 7, n. 3, p. 2616-2624, 2018. https://doi.org/10.20546/ijcmas.2018.703.302

TORRES, F. E.; TEODORO, P. E.; SAGRILO, E.; CECCON, G.; CORREA, A. M. Francisco Eduardo et al. Interação genótipo $\mathrm{x}$ ambiente em genótipos de feijão-caupi semiprostrado via modelos mistos. Bragantia, $\mathrm{v}$. 74, n. 3, 2015. https://doi.org/10.1590/1678-4499.0099 